\title{
Evaluation of Sales Accounting Information Systems Pt Bank Jatim Tbk
}

Anak Agung Gde Satia Utama*, Dito Novananta

Department of Accountancy, Faculty of Economics and Business, Universitas Airlangga, Indonesia

*Corresponding Author

Anak Agung Gde Satia Utama

\section{Article History}

Received: 08.12.2020

Accepted: 18.12 .2020

Published: 20.12.2020

\begin{abstract}
This study aims to analyze and evaluate the payroll accounting information system at the East Java Regional Development Bank. This study uses a descriptive qualitative approach — data obtained using observation and direct interviews. This study's analysis unit is internal control on the payroll stem, including organizational structure, authority stem, and recording procedures, healthy work practices, and qualified employees. The results of this elaboration indicate that the accounting information system carried out by the East Java BPD (Bank Pembangunan Daerah East Java/Jatim) is sufficient, with all internal controls being fulfilled. This research aims to improve the quality of accounting information systems in East Java BPD's payroll division in an integrated manner. Proposals that can be given are about increasing employee discipline, authorization, and responsibilities and recording official travel transactions. The contribution of this research is to provide recommendations for policymakers to improve the company's internal control. This research's added value lies in evaluating information systems that can be applied to divisions or other parts of the company.
\end{abstract}

Keywords: Information system, payroll control, employees, Bank Jatim.

\section{INTRODUCTION}

Companies can manage their accounting information systems. Accounting information generated from a financial statement is beneficial in order to prepare various projections. The company must have an internal control structure consisting of policies and procedures that have been established to provide reasonable guarantees that the company's objectives will be achieved [1-3]. The payroll system has so far been overlooked, so it does not cover fraud in recording employee salaries [4]. The company's internal control system is considered necessary because an internal control system can reduce fraud or corruption, and collusion activities in the East Java Regional Development Bank. The payroll system to be investigated is to change the manual-based system into a computerized system model [5-7]. Salary is remuneration or income expressed in money and determined by reciprocal agreements or by-laws or regulations $[8,5,9,10,4,11$, 12]. Payments are made based on a written work agreement by the company to workers employed for work that has been or will be employed or services that have been or will be provided. Payroll issues are a matter for personnel management (personnel). They are the most meaningful and essential aspects for employees and the company. Policies related to proper payroll are crucial to the employee and labor withdrawal rates. Two or several different people who are independently getting the same thing.

However, policies regarding promotion or promotion must also ensure that each job's salary compensation must be based on the Value (price) of the job [13]. The success of management is greatly influenced and depends on the accuracy of the information presented in various reports. The report must provide optimal benefits for those who need it to carry out the functions collected. Reasonable payroll procedures should be carried out effectively and efficiently [14; 6; 7; Ratnasari and Mahmud [11]; Sofwan and Zanah [12]. Therefore, relevant and accurate information is needed to communicate that will later be used for decision making by management. Based on the background, the problem in this research is: "What is the internal control system for employee payroll at the East Java Regional Development Bank?"

Copyright $\odot 2020$ The Author(s): This is an open-access article distributed under the terms of the Creative Commons Attribution 4.0 International License (CC BY-NC 4.0) which permits unrestricted use, distribution, and reproduction in any medium for noncommercial use provided the original author and source are credited. 


\section{TheOretical Foundation \\ Internal Control}

The term internal control arises after experiencing the development and refinement of the terms used before. Initially, in 1931 the term used was internal control which, according to the AICPA (American Institute of Certified Public Accountants) defines internal control as a tool in the field of bookkeeping, where an attempt is made to obtain correct numbers or accuracy of numbers by using two or several different people who are independently getting the same thing. Internal control is the organizational plan and methods used to maintain or protect assets, produce accurate and reliable information, improve efficiency, and to encourage compliance with management policies $[15,9,16$, $10,7,12]$

\section{Benefits of Internal Control}

The essential first attempt to enforce the discipline of operations in a company as a deterrent of fraud is to create effective internal control. All activities within the company require control. The internal control system's definition emphasizes the benefits to be achieved, not the elements that make up the system. Thus, the definition of internal control applies both in companies that manage information manually, by bookkeeping machines, and by computer $[1,14,10]$.

\section{Elements of Internal Control}

The main elements of the internal control system are as follows $[17,9,16,10,7,12]$ :

a. Organizational structure: This is a framework of the strict separation of responsibilities based on units' functions and levels formed. The principle in composing an organizational structure, namely the separation between each function that exists and a function, should not be given full responsibility for carrying out all stages of activities. This aims to create a mechanism for mutual control between functions optimally.

b. The system of authority and recording procedures in the organization: The organizational structure must be equipped with a description of the tasks governing each level's rights and authority along with all its ranks. The job description must be supported by procedural instructions in the form of task implementation accompanied by an explanation of the parties authorized to authorize standard procedures that must accompany activities, then related to the recording. Proper recording procedures guarantee the accuracy and reliability of data in the company. The transaction occurs if an authorized official has authorized it. Every document has valid evidence, initials, and signature of the official who authorizes it.

c. Strong work performance: Healthy work procedures are implementations made in such a way as to support the achievement of internal control objectives, which are demonstrated in several ways. The prudent element is essential in keeping so that no one handles transactions from the beginning to the end alone, must be rolling between employees, carrying out various tasks that have been given, checking deficiencies in implementation, and avoiding fraud.

d. Qualified employees: One of the main elements driving the organization is employees; employees must be qualified to have a quality image. In general, employee quality is determined by three aspects, namely education, experience, and morals. Not only quality but the appropriateness of responsibilities and division of tasks need to be considered. Qualified employees can be determined based on the recruitment process carried out to them, whether based on professional or based on charity.

\section{Understanding and Role of Employee Salaries for the Company}

A salary is remuneration in the form of money received by an employee due to his status as an employee who contributes to achieving its goals. Alternatively, it can also be said to be a fixed fee that a person receives because of his position in the company Law No. 13 of 2003 concerning workforce (article 1), that wages are the rights of workers received and expressed in the form of money in return from employers for workers to be determined and paid according to a work agreement, agreement, or statutory regulation, including benefits for workers and his family for a job and service that has been or, will be done [18].

\section{The Role of Employee Salaries for the Company}

The role of salaries can be reviewed from two parties, namely [5, 11]:

a) The employer aspect

Salary is an essential element in calculating the cost of production and components in determining the cost of goods that can determine the company's survival. Suppose a company gives too high a salary. In that case, it will result in a high base price as well, and if the salary is given is too low, it will cause the company to have trouble finding workers.

b) Aspects of work recipients

Salary is income received by someone and is used to meet their needs. Salary is not the only motivation of employees in achievement. However, salary is one of the essential motivations that encourage employees to excel. The level of salary given will affect employee performance and loyalty. 


\section{Relationship of Internal Control Systems with employee payroll}

The existence of continuity between the internal control system and employee payroll is needed in a company. This is done to avoid fraud or fraud. With internal control over payroll that is balanced, at least can prevent the possibility of loss [19, 7, 20]. Internal control is a tool for management in supervising payroll activities. Internal control is mainly based on the division of tasks and the separation of responsibilities between employees. The success of internal control depends on the awareness, willingness, and ability of employees to comply with the authority, duties, and responsibilities given to them [21]. Thus, the existence of reasonable internal control can realize the provision of a balanced salary and harmony with the company's systems and procedures. So the company has a guarantee to achieve the goals set.

\section{RESEARCH METHOD}

This type of research used in this study using descriptive qualitative methods. Descriptive qualitative research is data collected that takes the form of words or pictures rather than numbers. Written research results contain excerpts from data to illustrate and provide evidence of presentation. The reason for using qualitative research is that the conclusion cannot be generalized because the study does not use a sample but with a single study and does not aim to test the hypothesis $[22,9,7]$

The object to be examined by the author is the payroll accounting information system at the Regional Development Bank of East Java. The population consists of several documents that can support the payroll control system, including: (a) Payroll system and procedure, (b) Functions or related parts in payroll, (c) Personnel department documents that prepare and submit to the salary payment department various personnel activity forms, (d) Transaction documents related to the recording of payroll.

This study's type of data is secondary data, which is a source of research data obtained indirectly through intermediary media (obtained and recorded by other parties. Secondary data is generally in the form of evidence, notes, or historical reports arranged in an archive (documentary data. Secondary data in this study are in the form of archives or records in the East Java Regional Development Bank [13, 22, 14] Hanafi and Imelda [13, 23]; Hidayat [22]; Kasanah, Sulistyowati, and Credit [14].

In this study, the data used by researchers were sourced from documentary data, which is a type of research data that includes invoices, journals, letters, minutes of meetings, memos, or reports. The data is in the form of company documents in the East Java Regional Development Bank. Data collection techniques are part of the data testing process. Their results are used as adequate evidence to draw research conclusions. Field research is a way to obtain data by conducting direct research by making a list of questions that will support this thesis's preparation, which is submitted to certain parties in the company that is made as research objects. This fieldwork was carried out by observation, interview, and documentation.

This research has the object of research that is the payroll information system; the payroll information system evaluated is from the internal control system's perspective. The Internal Control System evaluated includes: Organizational structure, System of authority and recording procedures within the organization, Implementation of healthy work and qualified employees. The unit of analysis is the smallest unit of research object desired by researchers to classify data collection.

The researcher can determine the unit of analysis that best suits the research needs. While the data analysis technique used to solve this writing problem is to use qualitative descriptive techniques. Understanding data analysis techniques is arranging data sequences, organizing them into a pattern, category, and basic description unit so that themes can be found. The elements carried out to analyze the payroll system internal control are: organizational structure, the separation between staffing and finance. Done to prevent salary and wage receipts from making a misused salary list, the system of authority and recording procedures in the organization, excellent work performance, and qualified employees.

\section{RESULTS AND DISCUSSION}

\section{Payroll System PT. East Java Regional Development Bank Tbk}

In carrying out payroll appropriately, a good system and procedure are needed. The payroll system and procedure can be carried out correctly. It is necessary to have data or information in the form of documentary evidence relating to payroll activities. The payment method for employees of PT Bank Pembangunan Jawa Timur Tbk is based on the attendance list of employees collected by Payroll Staff and serving as assisting supervisors in employment/employee disability. The calculation of the total work time of employees is done at the end of the month. The salary method applied so far by the East Java Regional Development Bank is as follows: 


\section{Employee Checking Process on Payroll}

The employee checking process starts from the 15th to the 19th of every month by Recruitment and Staffing Staff. Staff recruitment and staffing data check both employee and employee transfers in the Payroll Menu. The mutation of employees or new employees added regular pieces of ASTEK and Non-routine pieces of Infaq deductions, Cooperative deductions, Dharma Wanita deductions, Foster Children deductions, and BPR deductions, BTN deductions, and IIKBJ Arisan deductions. Staff recruitment and staffing data check both employee mutations and employees who leave the Payroll Menu. In the mutation of employees or outgoing employees, the regular pieces of ASTEK and the nonroutine pieces are deleted in the form of infaq deductions, cooperative pieces, women's Dharma deductions, foster children pieces, BPR deductions, BTN deductions, and IIKBJ deductions.

\section{Posting Process}

The Posting process starts on the 20th to the 24th of every month by Payroll Staff. The Payroll Staff of the HR Division will post and branch make a nominative data on employees and employees who experience changes in special allowances for either temporary replacement (PGS) or temporary official allowances (PJS). The branch makes the nominative then matches the nominative that has been posted by the Payroll Staff of the HR Division, after which the Branch checks employee data (JOB GRADE, PERSONAL GRADE, Pieces, Special Allowances, Salary Recap of Control, Salary Upload Recap, PHDP I, PHDP II, check and print astek or BPJS) if it does not match, the branch corrects the nominative if it matches. There is no change; the Branch General Staff downloads the create text in the HR Online Payroll Portal. After the Branch General Staff downloads Create Text, it is expected that the Branch General Staff will match the create text (Payroll and Cut) with the nominal uploads. Cuts in the nominative salary uploads must be the same or match.

\section{Upload Process}

Payroll Upload Process on the 25th of each month By Payroll Staff, After the HR Division fixes the upload process, the General Branch Staff downloads the payroll list. In addition to the Payroll Procedure above, PT. East Java Regional Development Bank, Tbk. also considers other income, namely Food Eating, Overtime.

\section{Calculation Procedure}

a) The general policy stipulated in the procedure for calculating money for permanent employees of PT. East Java Regional Development Bank, Tbk. is as follows:

b) Each employee who attends must fill out absentee employees present the attendance card by inserting the known system with Fingerprint and Id card clerks where the machine will automatically record the time comes every employee to come to work.

c) All data on each employee's attendance time that has been recorded and stored automatically on the card, at almost the end of the month, will be collected and recapitulated by the TU for Headquarters and General for Branches.

d) Employee Meals are affected by the employee absentee data; if the employee cannot come to work, the employee's meal allowance is automatically reduced.

\section{Overtime Wage Calculation Procedure}

The general policy stipulated in the procedure for calculating overtime wages for permanent employees of PT. East Java Regional Development Bank. Every overtime activity that employees will carry out must be based on an overtime warrant (SPL) approved by the Head of Division or Branch Manager concerned. The SPL must be signed by the Head of Division or Branch Manager as proof of overtime.

\section{Elements Related to Internal Control of the Payroll System of Bank Jatim, Tbk.}

1. Organizational structure. The organizational structure is a framework (framework) division of functional responsibilities to organizational units formed to carry out the company's main activities. Payroll functional responsibility division at PT Bank Pembangunan Daerah Jawa Timur Tbk as follows:
a) Human Resources Staff and Branch General Staff
b) Customer Service Staff
c) Human Resources Supervisor and Branch General Supervisor

2. The system of authority and recording procedures in the organization. In an organization, each transaction only occurs based on authorization from an official who has the authority to approve the transaction. Therefore, an organization must be made in a system that regulates the distribution of authority for authorization for the implementation of each transaction, in the system of authority in PT Bank Pembangunan Jawa Timur Tbk namely: 
a) The Human Resources Staff and Branch General Staff carry out the administration of benefits provided to employees. While secretarial activities, general and internal services that support the operations of the Branch Office and the network under it as long as these activities are under the Branch Office's authority, as well as making payroll and uploading employee salaries.

b) Human Resource Supervisors and Branch General Supervisors supervise the employees under it (Human Resources Staff and Branch General Staff)

c) Customer Service Staff carry out salary transfer to the Employee Account after obtaining salary data from HR staff and branch general staff.

3. Healthy practices in carrying out tasks. The division of functional responsibilities and authority systems and established recording procedures will not be carried out properly if ways are not created to ensure sound practices in their implementation. The ways generally were taken by PT Bank Pembangunan Jawa Timur Tbk in creating healthy practices are:

a) The use of printed serial numbered forms whose use must be accounted for by the authorities.

b) Inspection by Internal Audit of PT Bank Pembangunan Daerah East Java Tbk

c) Turnover office (job rotation) by the HR Division.

d) Every transaction may not be carried out from beginning to end by one person or one subdivision unit, without any interference from the person or unit of the recorded subdivision.

e) The requirement for taking leave for eligible employees.

4. Qualified employees. Of the four elements of internal control, employee quality is an essential element. Suppose the company has competent and honest employees. In that case, other elements of control can be reduced to a minimum, and the company can still produce reliable financial accountability.

\section{DISCUSSION}

Salary and wage management systems run by PT. Bank Pembangunan Daerah East Java Tbk is done computerized. This method is very useful in measuring the company's size because it can save time in the distribution of employee salaries, and the level of security can be maintained for the organizational structure at PT. The Regional Development Bank of East Java Tbk is well structured. The functional duties and responsibilities are separated clearly and expressly related to the company's internal control. The employment and policy systems and the payroll system created by the company are also well-structured and clear. However, there are still a few shortcomings or weaknesses in its payroll activities, which, if only slightly, will affect the level of efficiency of the company's internal control. This can be seen in employee nominative matching procedures, where branches still need to match employee nominatives. This is still considered inefficient for the size of a large enough company. Because if the company still uses the system, it is feared that there will still be mistakes between the Branch General Staff and Headquarters. This is very influential in terms of payroll, where the magnitude of errors can still occur. Judging from this, it will be even better if the HR Division Headquarters checks employee transfers without having to match the branch because the Staffing Staff should know better than the Branch, therefore for the function of the branch matching it should be eliminated because sometimes there are still frequent errors for pieces or additional benefits for the position.

\section{Constraints on Payroll Procedures of PT. East Java Regional Development Bank Tbk}

The implementation of activities in any company must have been faced with a problem in connection with the activities that have been carried out as is well known that in a company there can be a problem that is realized or not realized its existence, which can lead to obstruction of the company's goals to be achieved. Payroll systems and procedures of PT Bank Pembangunan Jawa Timur Tbk as a whole are said to be good because the payroll system and procedures have met elements of adequate controls, it can be seen from the functions or parts associated with the salary system related to the activities of the accounting information system, already involves the functions or parts related to the payroll system, as well as the practice healthy, has been running well so that the payroll accounting system at PT Bank Pembangunan Daerah East Java Tbk has fulfilled the internal control elements commonly used by companies.

The results of the analysis of the elements of internal control over the payroll accounting system at PT Bank Pembangunan Daerah East Java shows that there are obstacles in the payroll system as long as those encountered in research on the payroll system are as follows:

1. Employee salaries are not affected by late employee attendance data; employee attendance data only affect employee meal costs.

2. Employee attendance that should use two intermediaries, namely fingerprints and employee $I D$ cards, can be manipulated using only one. The function of one of these components does not function fully.

3. Official Travel Data still uses manual recap in calculating taxes, thus allowing user input errors to occur. 
4. The GL or COA Account on Official Travel for Outsourcing experts or outsourcing is still combined with the $G L$ or $C O A$ Account on Official Trip for Employees. Control of official travel issued to employees is difficult to control.

5. The division of responsibilities for implementing a transaction or payroll activity in the salary checking function is carried out by the HR Division and General Branch Staff.

\section{Solutions to Obstacles in Payroll Procedures of PT Bank Pembangunan Daerah East Java Tbk}

The following are some of the solutions to the above problems from the author to overcome the obstacles that occur:

1. For late employee absence, problems do not affect the salary deduction of employees. For employee absences that only use one condition, the company should make a rule that for employees who are late, the company will reduce salaries or do not get food allowance from the day the employee is late. Moreover, provide rules to employees required to use two intermediaries in attendance, namely fingerprint and id cards of employees as function id card employees are not fully used if using fingerprint only. Using id card alone could lead to fraud in employee absenteeism, for example, illegal absence. Employees who have been proven to have committed a company violation should be punished by providing these regulations will deter employees who are often late.

2. For official trips that still use manual recap and $C O A$, which are used for employees and power experts, are still the same. PT Bank Pembangunan Daerah Jawa Timur Tbk should use an application system in inputting official employee trips to minimize officers making mistakes. The company makes its COA for employee official travel to control how much company revenues outweigh the company's expenses.

3. For payroll responsibilities between the HR Division and Branch General Staff, full responsibility should be held by the HR Division because, in the implementation, there are errors in the transfer of transactions, the mismatch between Payroll Online Portal HR and existing transactions branched out. Therefore the HR Division holds full responsibility for payroll, so the nominative that makes the HR Division Branch just do the transaction, to minimize errors.

\section{Payroll Accounting System Analysis in supporting the effectiveness of Payroll Internal Control of PT Bank Pembangunan Daerah East Java}

After seeing the description in the previous chapters, it can be said that the accounting information system regarding payroll that has been applied through practice at PT. Bank Pembangunan Daerah East Java Tbk is considered to be sufficient and beneficial for the company. By using an accounting system, all activities, especially activities related to payroll, can be carried out properly, where it can reduce the risk of errors in managing employee salaries, security levels can be maintained and the level of accuracy, shortening the time needed to make documents containing data and records regarding employee data, financial statements data of relevant company documents, especially regarding payroll records. So with this convenience, all activities that do not need to be carried out can be effectively, efficiently, and accurately. This is also supported by the fulfillment of the accounting information system's objectives that can support internal control over payroll in the company.

As discussed earlier, the internal control element is divided into four components. In this study, the authors analyze the internal control carried out by PT Bank Pembangunan Daerah East Java Tbk, whether it has been appropriately implemented and adequately. Implementation of reasonable internal control aims to achieve effectiveness and work efficiency within the scope of payroll calculations. The following are control activities carried out by PT Bank Pembangunan Daerah East Java Tbk:

1. Organizational structure. PT Bank Pembangunan Daerah East Java Tbk. has the right organizational structure, reflecting the responsibilities that exist in achieving the company's goals. The principle in arranging the organizational structure, namely the separation between every existing function of staff, supervisors, subdivision leaders, division leaders, operational leaders, and leaders, the separation of functions is done to avoid accidental or accidental mistakes that can cause company losses.

2. System of authority and recording procedures in the organization. The organizational structure must be equipped with job descriptions that regulate each level's rights and authority, along with its entire staff. Each division head has subordinates in carrying out the responsibilities following the part being handled in its activities. The superior authorization system for subordinates has been fully implemented properly.

3. Strong work performance. Healthy work procedures are implementations made in such a way as to support the achievement of internal control objectives, which are demonstrated in several ways. The element of prudence (prudential) is essential if nobody handles the transaction from start to finish alone, must be rolling among employees, carrying out a variety of tasks that have been given, check for deficiencies in implementation, and avoid fraud.

4. Qualified staff. One of the main elements driving the organization is employees; employees must be qualified to have a quality image. In general, employee quality is determined by three aspects, namely education, experience, and morals. Not only quality but the appropriateness of responsibilities and division of tasks need to be considered. 
According to the author's observations, the reliability of internal control at PT Bank Pembangunan Jawa Timur Tbk as a whole is quite adequate. In terms of Organizational Structure, Authority System and Procedure for Recording in Organizations, Healthy implementation of work and qualified employees are considered more effective in carrying out internal control of payroll in the company. Thus it is apparent that with the fulfillment of many elements and payroll internal control objectives applied at PT Bank Pembangunan Daerah East Java, Tbk can be declared quite effective.

\section{CONCLUSION}

The organizational structure of PT. Bank Pembangunan Daerah East Java Tbk has been well structured, and the control environment for the organizational structure has been fulfilled. It has been carried out under a structured theory where the level of authority, duties, and responsibilities has been clearly described. The suggestions that can be erected are: (1). Address weaknesses in absenteeism of employees using one of the components of attendance, should a Human Resources Department made the Decree related to the attendance of employees who require the use of two components, namely the fingerprint and ID cards of employees so that the function of both components are fully used and for those who still violate sanctioned. (2). To improve employee discipline, PT. The Regional Development Bank of East Java Tbk runs sanctions for employees who arrive late and not just regulations. (3). For Travel Officials, Employees, and power experts should be created or opened a different GL (COA) account (new). It can be monitored how much expenditure for official travel staff and power experts can facilitate the calculation of taxes. And (4). For payroll responsibilities between the HR Division and Branch General Staff, full responsibility should be held by the HR Division because, in the implementation, there are errors in the transfer of transactions, the mismatch between Payroll Online Portal HR and existing transactions branched out. Therefore the HR Division holds full responsibility for payroll, so the nominative that makes the HR Division Branch just do the transaction, to minimize errors.

\section{REFERENCES}

1. Karim, A. (2019). "Salary information systems in the labuhanbatu region telkomsel cooperation." INFOTEK Journal, 4(3): 18-27.

2. Margareta, V., Tunjung, S., \& Elana, E. Y. (2020). "Evaluation of production will account information systems in the effectiveness of internal control pt. Tm." Journal of contemporary accounting (JAKO) 12(1): 10-19.

3. Sofwan, S.V., \& Laelatul, Z. (2020). "Internal control system and production examination procedure in pt daliatex kusuma." ACCURATE: Accounting Scientific Journal, 11(April): 90-105.

4. Ogi, G. P., Pangemanan, S. S., \& Pontoh, W. (2020). Analisis pengendalian intern atas penerimaan kas pada pt. Mandala multifinance, tbk cabang manado. Going concern: jurnal riset akuntansi, 15(2), 124-130.

5. Yulisetiarini, D., \& Prahasta, Y. A. (2019). The Effect Of Price, Service Quality, Customer Value, And Brand Image On Customers Satisfaction Of Telkomsel Cellular Operators In East Java Indonesia.

6. Maria, B., Vionalisa, C., Halim, E.M., \& Inggriani, E. (2020). "Internal control ipteks in the consumptive credit liquiding procedure in pt. Bank sulutgo main branch."Journal of Science and Technology Accounting for Communities, 4(1): 8-13.

7. Ogi, G. P., Pangemanan, S. S., \& Pontoh, W. (2020). Analisis pengendalian intern atas penerimaan kas pada pt. Mandala multifinance, tbk cabang manado. Going concern: jurnal riset akuntansi, 15(2), 124-130.

8. Hidayat, F. (2020). "Analysis of sharia general bank structure, conduct and performance in indonesia." Intellectivity: journal of economy, social \& humaniora 01 (06): 32-42.

9. Kasanah, N.N., Nur, W. S., \& Kasubag, K. (2020). "As an effect of internal control in bpr Y Employee and General Credit Provision System as Internal Control Efforts at BPR Y." Journal of Economic, Public, and Accounting (JEPA), 2(2): 129-44.

10. Maria, B., Vionalisa, C., Halim, E.M., \& Inggriani, E. (2020). "Internal control ipteks in the consumptive credit liquiding procedure in pt. Bank sulutgo main branch."Journal of Science and Technology Accounting for Communities, 4(1): 8-13.

11. Ratnasari, I., \& Ashadi, M. (2020). "The Effect of Salary and Incentives on the Performance of Employees in the Production Section of PT. Uniplastindo Interbuana Pandaan. "Journal of Business Management and Innovation Applications Volume, 2(2): 66-79.

12. Sofwan, S.V., \& Laelatul, Z. (2020). "Internal control system and production examination procedure in pt daliatex kusuma." ACCURATE: Accounting Scientific Journal, 11 (April): 90-105.

13. Hanafi, M. A., \& Imelda, E. (2020). Faktor-faktor pengaruh kinerja keuangan bank. Jurnal Paradigma Akuntansi, 2(1), 166-175.

14. Kasanah, N.N., Nur, W. S.I., \& Head of Credit. (2020). "AS AN EFFECT OF INTERNAL CONTROL IN BPR Y Employee and General Credit Provision System as Internal Control Efforts at BPR Y." Journal of Economic, Public, and Accounting (JEPA) 2(2): 129-44.

15. Dwi, A., \& Lely, D. (2020). "The Effect of Internal Control, Motivation, Compensation, and Leadership on Employee Performance." Wise Scientific Magazine, 17(1): 81-93. 
16. Margareta, V., Tunjung, S., \& Elana, E.Y. (2020). "Evaluation of production will accounting information systems in the effectiveness of inter-nal control pt. TM. " Journal of contemporary accounting (JAKO) 12 (1): 10-19.

17. Dwi, A., \& Lely, D. (2020). "The Effect of Internal Control, Motivation, Compensation and Leadership on Employee Performance." Wise Scientific Magazine, 17(1): 81-93.

18. Ratnasari, I., \& Ashadi, M. (2020). "The Effect of Salary and Incentives on the Performance of Employees in the Production Section of PT. Uniplastindo Interbuana Pandaan. "Journal of Business Management and Innovation Applications Volume, 2(2): 66-79.

19. Mendoza, M. D., \& Putri, T. T. A. (2020). Payroll System Design With SDLC (System Development Life Cycle) Approac. Jurnal Mantik, 4(1, May), 27-32.

20. Pangaribuan, D. Government governance implementation, role of accountability performance system and risk management to fraud detection andprevention.

21. Pan, G.D. (2019). "Government governance implementation, role of accountability performance system and risk management to fraud detection and prevention." 1 (2): 77-98.

22. Hidayat, F. (2020). "Analysis of structure, conduct and performance of sharia banks in indonesia." intellectivity: journal of economy, social \& humaniora, 01(06): 32-42.

23. Hanafi, Marcellus Anggara, and Elsa Imelda. (2020). "Factors influencing bank financial performance." Journal of Accounting Multiparadigm Tarumanagara, 2(1): 166-75.

24. Mendoza, M. D., \& Putri, T. T. A. (2020). Payroll System Design With SDLC (System Development Life Cycle) Approac. Jurnal Mantik, 4(1, May), 27-32. 